\title{
Adenovirus Death Protein
}

National Cancer Institute

\section{Source}

National Cancer Institute. Adenovirus Death Protein. NCI Thesaurus. Code C17989.

An adenovirus nuclear membrane glycoprotein synthesized from the E3 transcription unit

in large amounts late in infection. It is required for efficient lysis of infected cells. It is being investigated for use in targeting tumors for death by a suicide mechanism. 